\title{
HUSBAND-WIFE HOMICIDE: AN ESSAY FROM A FAMILY LAW PERSPECTIVE
}

\author{
MARGaret Howard*
}

I

INTRODUCTION

Homicide traditionally has been a matter between family, acquaintances, and friends. ${ }^{1}$ This fact is not particularly surprising, given the reasonable expectation that one would have more reason to kill an acquaintance than a stranger. It would seem to follow that spouses and other intimates would have the most reason of all to kill each other. Yet we recoil from the very idea, clinging to the belief that intimate relationships are characterized by tenderness and love. That they are not always so characterized is evident in the fact of spousal ${ }^{2}$ violence and homicide.

Most homicides are committed with firearms, ${ }^{3}$ and these weapons also play a role in the more specialized group of homicides that occur between spouses. One goal of all gun control proposals is to reduce the overall number of homicides by reducing the number of homicides committed with firearms. ${ }^{4} \mathrm{~A}$ particularly poignant subissue, however, is how to keep people from killing those they live with and (supposedly) love. This article looks at gun control issues from the viewpoint of family law and comments on gun control in the context of husband-wife homicide. In the process, the article also reviews what empiricists have concluded about these homicides and points out areas in which further inquiry would be fruitful.

Much of the gun control literature consists of recurring debate on a group of propositions that are relevant to all killings between friends and relatives. Indeed, debate on these propositions is much of the gun control literature. Two of these propositions are particularly interesting to a family law specialist, namely:

Copyright $\odot 1986$ by Law and Contemporary Problems

* Associate Professor of Law, Vanderbilt University School of Law.

1. M. Wolfgang, Patterns in Criminal Homicide 203-21 (1966).

2. Police reports, from which much of the data concerning homicide is extracted, are often unclear about marital status. See, e.g., 11 D. Mulvihill, M. Tumin \& L. Curtis, Crimes of Violence 247 n.43 (1969) (staff report submitted to the National Commission on the Causes and Prevention of Violence); see also Zimring, Mukherjee \& Van Winkle, Intimate l'olence: .t Study of Intersexwal Homicide in Chicago, 50 U. Chi. L. Rev. 910,913 n.ll (1983). This article, through some degree of necessity. considers all intimate couples as equivalent to spouses.

3. See, e.g., Fedfral Bureau of Investigation, 1981 Uniform Crime Reports, Crimf in the United States 10, 12 (1982) (hereinafter cited as UCR (date) (the FBI has published a number of these reports; the specific publication will be identified by the year of coverage) I.

4. Hardy \& Stompoly, Of Arms and the Lazw, 51 ChI.-Kent L. REv. 62, 93 (1974). 
(1) Spousal homicides are spontaneous "crimes of passion" that result from momentary rages arising from the heat of circumstances, rather than from a fixed determination to kill.

(2) If deprived of guns, spouse killers either would not substitute another weapon or would substitute a weapon less lethal than a gun.

Proponents of gun control rely on the accuracy of these propositions to support the conclusion that a firearms ban would reduce domestic and acquaintance homicides, conceding, of course, that contract killings and felony murders would be unaffected. ${ }^{5}$ Much of the critical literature, therefore, consists of attacks upon the relevance and reliability of the evidence arguably supporting each of these propositions. ${ }^{6}$ A family law specialist is in no position to leap into that fray. In candor, even stating the propositions as they appear above telescopes the relevant arguments and leaves out some logically necessary steps. ${ }^{7}$ Such simplification, however, permits a closer focus on the portion of the debate that is most interesting from the perspective of family law. From that perspective, it seems that gun theorists on both sides of the issue could profit from consideration of the spouse abuse literature. In fact, if they can be charged with any omission, it is a failure to examine and learn from that body of literature.

A full review of either the spouse abuse or the spousal homicide literature is obviously beyond the scope of this commentary. Instead, the article reviews what is known about husband-wife homicides and then highlights the spouse abuse literature in order to examine the gun control propositions stated above in light of the current understanding of spouse abuse.

II

\section{Empirical Data on Spousal Homicides}

A synopsis of current knowledge about spousal homicides must unfortunately begin with the observation that surprisingly little is known about this phenomenon. Much information that would be helpful is simply

5. "Sophisticated proponents of banning handguns concede there is no way to get them away from terrorists or the professional robber, burglar or contract killer . . . ." Kates, Some Remarks on the Prohibition of Handguns, 23 ST. Louis U. L.J. 11, 16 (1979); see also Beha, "And Vobody Can Get lou Out": The Impact of a Mandatory Prison Sentence for the Illegal Carrying of a Firearm on the Lise of Firearms and on the Administration of Criminal Justice in Boston, 57 B.U.L. REv. 96, $150 \mathrm{n.31}$ (1977) (reporting the impression of police officers and defense attorneys that the mandatory sentencing law would not affect "patterns of serious crime," and the belief of jail detainees that the law probably would not affect "intentional, predatory crimes").

6. See, e.g., G. Newton \& F. Zimring. Firearms and Violence in American Life (1969) (staff report submitted to the National Commission on the Causes and Prevention of Violence); J. WRIGHT, P. Rossi \& K. Daly, Under the Gun: Weapons, Crime, and Violence in America 361 -411 (1983); Hardy \& Stompoly, supra note 4, at 102-10; Kleck \& Bordua, Assumptions of Gun Control, in WHY Handgun Bans Can't Work 77 (D. Kates ed. 1982); Zimring, Is Gun Comtrol Likely to Reduce Iiolent Killings?, 35 U. CHI. L. REv. 721 (1968).

7. In addition to the two propositions stated, proponents of gun control assert that firearms are more lethal than other weapons, that spousal killers are ordinary law-abiding citizens who kill only because they have access to a gun during their momentary rage, and that these essentially lawabiding persons would comply with a firearms prohibition. 
not reported, ${ }^{8}$ and much of the empirical data is quite dated and drawn from narrow samples. 9 These drawbacks, along with inconsistent results between studies, make even tentative conclusions all the more speculative.

While the facts indicate that most homicides in the United States are committed with firearms, and that the handgun accounts for roughly half of all homicides, ${ }^{10}$ no clear picture is available of the relative roles various weapons play in spousal killings. The first statistics on choice of weapon in spousal homicides were reported by Wolfgang in his classic, but now dated, study of Philadelphia homicides. ${ }^{11}$

TABLE 1

Husband-Wife Criminal Homicide by Method ${ }^{12}$ (100 CASES)

\begin{tabular}{lccc}
\hline Method & Total & $\begin{array}{c}\text { Husband Killed } \\
\text { by Wife } \\
(\%)\end{array}$ & $\begin{array}{c}\text { Wife Killed } \\
\text { by Husband } \\
(\%)\end{array}$ \\
\hline Shooting & $(\%)$ & 15 & 19 \\
Stabbing & 34 & 30 & 16 \\
Beating & 46 & 0 & 15 \\
Other & 15 & 2 & 3 \\
Total & 5 & 47 & 53 \\
\hline
\end{tabular}

A 1967 survey of seventeen United States cities ${ }^{13}$ found that firearms were utilized in twenty percent more of the spousal homicide cases than Wolfgang reported. Firearms were increasingly utilized by both husband-offenders and wife-offenders.

8. The FBI's Uniform Crime Reports (UCR), for example, from which much of the data on homicide is derived, did not state the percentage of all killings that were husband-killing-wife and wife-killing-husband for years prior to 1977. The UCR merely reported the percentage of all killings that were committed by spouses.

9. Wolfgang's classic study, for example, is based on homicides in Philadelphia that occurred between 1948 and 1952. See M. WolfGang, supra note 1 , at 5 .

10. The FBI's Uniform Crime Reports indicate that the percentage of all homicides committed with firearms has, since 1966, ranged from a low of $60 \%$ in 1966 to a high of almost $68 \%$ in 1974 . UCR (1972), supra note 3, at 9; UCR (1977), supra note 3, at 10; UCR (1981), supra note 3, at 10; see also Zimring, supra note 6 , at 726 (reporting that in Chicago in 1966,52\% of homicides were committed with firearms, $30 \%$ with knives, $8 \%$ with other weapons, $10 \%$ with no weapon, and $1 \%$ with unknown weapons).

11. As mentioned above, Wolfgang's findings were based on Philadelphia homicides committed between 1948 and 1952 . See M. WolfGANG, supra note 1, at 5.

12. Id. at 213 . Wolfgang found the percentage of spousal homicides committed with firearms $(34 \%)$ virtually identical to the percentage of overall homicides committed with firearms $(33 \%)$. Id. at 85 .

13. The Task Force on Individual Acts of Violence of the National Commission on the Causes and Prevention of Violence prepared a national survey on victim and offender patterns in homicide and three other major crimes. The survey collected 1967 offense and arrest data from 17 large cities. representing all regions of the United States. The data were then weighted to project national figures as accurately as possible. For a detailed description of the method, see D. MULiHILL. M. Tumin \& L. Curtis, supra note 2, at 259-66. 
TABLE 2

Husband-Wife Criminal Homicide by Means of Inflicting INJURY ${ }^{14}$

(105 CASES)

\begin{tabular}{lccc}
\hline Means & Total & $\begin{array}{c}\text { Husband Killed } \\
\text { by Wife } \\
(\%)\end{array}$ & $\begin{array}{c}\text { Wife Killed } \\
\text { by Husband } \\
(\%)\end{array}$ \\
\hline Firearm & $(\%)$ & 27 & 27 \\
Sharp Instrument & 54 & 22 & 11 \\
Body & 33 & 0 & 6 \\
Other & 6 & 2 & 5 \\
Total & 7 & 51 & 49 \\
\hline
\end{tabular}

More recent data, ${ }^{15}$ which come from the FBI, reveal a still increased role for firearms in spousal homicide.

TABLE 3

INTIMATE HOMICIDE BY WEAPON ${ }^{16}$

(1525 CASES)

\begin{tabular}{lrrrr}
\hline Weapon & $\begin{array}{c}\text { Husband } \\
(\%)\end{array}$ & $\begin{array}{c}\text { Wife } \\
(\%)\end{array}$ & $\begin{array}{c}\text { Identity of Victim } \\
\text { Boyfriend } \\
(\%)\end{array}$ & $\begin{array}{c}\text { Girlfriend } \\
(\%)\end{array}$ \\
\hline Gun & 67 & 62 & 58 & 54 \\
Knife & 30 & 16 & 38 & 19 \\
Blunt Object & 2 & 5 & 1 & 5 \\
Other & 1 & 17 & 2 & 22 \\
\hline Number & 553 & 547 & 216 & 209 \\
\hline
\end{tabular}

14. Id. at 300 . The survey found a much larger role for firearms in spousal homicides $(54 \%)$ than for homicides overall $(47 \%)$. Id. at 370 .

15. There are two other studies of limited scope. One, conducted by University of Florida researchers, examined 34 persons ( 23 men and 11 women) from north central Florida accused of killing their spouses between 1970 and 1980 . This study found handguns "by far the most popular weapon for killing a spouse, followed by shotguns and rifles." Jones, When Battered Women Fight Back, Barrister, Fall 1982, at 12, 15 .

Another study, also of limited scope, found an almost equal role for firearms and knives (the latter category also including household implements such as kitchen utensils, hand tools, lye. gasoline, steam irons, garden hoses, women's shoes, etc.). This study of inmates at California's Institution for Women, conducted at two different intervals in the 1960's, found that a knife or household implement was used in $35 \%$ of homicides and a gun in $34 \%$. If knives and household implements had been separately categorized, guns probably would have been the most frequently used homicide weapon. Ward, Jackson \& Ward, Crimes of V'iolence by IVomen, 843, 871, app. 17 io D. Mulvihill, M. Tumin \& L. CurTis, supra note 2.

16. Cook, The Role of Firearms in liolent Crime: An Interpretive Revipur of the Literature, in Criminat. Violence 236, 255 (M. Wolfgang \& N. Weiner eds. 1982) (citing Federal Burfau of Investigation. SUPPLEMENTAI. HOMICIDE. REPORTS (1976 \& 1977)). 
Significantly, these most recent data report a percentage of firearms usage in spousal homicide that roughly equals the frequency of firearms use in homicides generally for the same years. ${ }^{17}$

The progression of these data suggests the possibility that firearms are being used in an increasing percentage of spousal homicides-a conclusion at variance with the relatively stable percentage of all homicides committed with firearms over the last fifteen years. Research is clearly needed on the preliminary question of what weapons spouses actually are using against each other before gun control policies designed to reduce spousal killings can be formulated.

Data across the studies, both recent and dated, are consistent in finding that wives and husbands are domestic homicide victims in roughly equal numbers. Both Wolfgang and the 1967 survey found that of all spouses killed, $53 \%$ and $52 \%$, respectively, were wives and $47 \%$ and $49 \%$, respectively, were husbands. ${ }^{18}$ Calculations based on FBI figures for recent years reveal that husbands are victims in $38 \%-45 \%$ of spousal homicides and wives are victims in $55 \%-62 \%$ of the cases. ${ }^{19}$ Thus, the risk posed to husbands and wives by spousal homicide is roughly equal.

Only Wolfgang has compared the circumstances ${ }^{20}$ surrounding spousal homicides with homicides generally. Unfortunately, comparison is hampered

17. In 1976 and $1977,63.8 \%$ and $62.5 \%$, respectively, of all homicides were committed with firearms. UCR (1977), supra note 3 , at 10 . Table 3 in the text reveals that 948 of the 1525 husbandwife, boyfriend-girlfriend victims $-62 \%$-were killed by guns.

18. See supra Table $1 \&$ Table 2.

19. Calculations based on the figures reported in the Uniform Crime Reports reveal the following percentages of spousal homicide victims who were husbands and wives, for recent years:

$\begin{array}{lcc}\frac{\text { Year }}{1984} & \text { \% Husbands } & \frac{\text { \% Wives }}{298} \\ 1983 & 38 & 62 \\ 1982 & 41 & 59 \\ 1981 & 41 & 59 \\ 1980 & 44 & 56 \\ 1979 & 43 & 57 \\ 1978 & 46 & 54 \\ 1977 & 43 & 57\end{array}$

UCR (1977), supra note 3, at 12; UCR (1978), supra note 3, at 9; UCR (1979), supra note 3, at 11; UCR (1980), supra note 3, at 12; UCR (1981), supra note 3, at 11; UCR (1982), supra note 3, at 11; UCR (1983), supra note 3, at 11; UCR (1984), supra note 3 , at 11 .

Thus, the risk posed to husbands and wives when a spousal homicide occurs remains roughly equal, although wives have been victims in increasingly greater proportions in recent years than Wolfgang and the 1967 Survey found.

20. Distinctions should be drawn between intent, motive, and circumstances. "Intent" within the meaning of criminal law, and this commentary as well, "is an essential legal element of crime and refers to the actor's intellectual ability to comprehend the nature of his act": it is "the resolve to commit an act." M. WolfGang, supra note 1 , at 187; accord D. Mulvihill, M. Tumin \& L. Curtis, supra note 2, at 229.

"Motive" usually refers to the surrounding circumstances providing "the inducement which stimulates a person to commit" the act. M. WolfGANG, supra note 1 , at 187 . "Motive" is also used in this sense by the Uniform Crime Reports. See, e.g., UCR (1982), supra note 3, at 12; acrord D. Mulvihill, M. Tumin \& L. Curtis, supra note 2, at 229. The term is confusing, however, because it 
because he did not list the same categories of circumstances for each group. At least one important conclusion is possible nonetheless: Quarrels are much more deadly when they occur between husbands and wives. Wolfgang found that $66 \%$ of spousal homicides derive from family quarrels and altercations, ${ }^{21}$ while $59 \%$ of overall homicides arise out of domestic quarrels and various types of altercations. ${ }^{22}$ These categories account for $72 \%$ of the husbands killed and $60 \%$ of the wives killed, ${ }^{23}$ but only for $63 \%$ of male victims and $48 \%$ of female victims overall. ${ }^{24}$

Place of occurrence also distinguishes spousal homicides from homicides generally. Although approximately one-third of homicides occur in the home, ${ }^{25}$ Wolfgang found that $84 \%$ of spousal homicides take place there. ${ }^{26}$ Wolfgang also noted that the bedroom is a more lethal place for wives, with $45 \%$ of wives, but only $23 \%$ of husbands, killed in that room. ${ }^{27}$ On the other hand, kitchens are more lethal for husbands; $40 \%$ of husbands, but only $19 \%$ of wives, were killed there. ${ }^{28}$

The place a spousal homicide occurs affects the weapon utilized. Of the nineteen husbands killed in the kitchen, Wolfgang found that seventeen were stabbed and two were shot. Of the twenty-one husbands killed elsewhere in the home, ten were shot, ten were cut or stabbed, and one was soaked with kerosene and burned. ${ }^{29}$ Thus, while wives tend to stab their husbands to death rather than shoot them, ${ }^{30}$ this preference appears to derive from the tendency of wives to kill their husbands in the kitchen, where knives are readily available. Husbands, on the other hand, do not show an overall preference for one weapon in killing their wives. But Wolfgang found that the weapons utilized by husbands also varied according to the place of the killing. ${ }^{31}$

implies that underlying sociological and psychological causes and unconscious motivations are being presented, when they are not. "Motive" and "motivation," therefore, should be reserved for reference to the deeper levels of causes. Provoking incidents and interactions between victims and offenders should be labeled "circumstances."

21. M. WOLFGANG, supra note 1 , at 213.

22. Id. at 191 .

23. Id. at 213 .

24. Id. at 191 .

25. D. Mulvihill, M. Tumin \& L. Curtis, supra note 2, at 221. An examination of all deaths in California for the first six months of 1975 revealed that approximately $53 \%$ of all firearm homicides occurred in residences. Of firearm homicides occurring in residences and involving victims and offenders who were related or acquainted, approximately $60 \%$ were committed with handguns. Hardy, Firearm Oumership and Regulation: Tackling an Old Problem with Reneried Vigor; 20 WM. \& MARY L. REv. 235, 260-61 \& n.157 (1978).

26. M. WolfGang, supra note 1 , at 213.

27. Id. at 215 .

28. Id.

29. Id. at $215-26$.

30. Thirty $(64 \%)$ of the 47 husbands were stabbed and $15(32 \%)$ were shot. Two were killed by other methods. Sep Table 1, supra at 65.

31. M. Wolfgang, supra note 1, at 215-16. 
Finally, Wolfgang found that spousal homicides tend to be more violent than homicides generally ${ }^{32}$ and are, in fact, among the most violent of all homicides. He found that the most violent homicides-those involving five or more acts of stabbing or shooting-constituted twenty-four percent of spousal killings, but only eighteen percent of all violent homicides. ${ }^{33}$ Furthermore, the most violent homicides tend to occur in the home because most spousal killings take place there, ${ }^{34}$ and homicides arising out of domestic quarrels, which are the circumstances predominating in spousal killings, are proportionately among the most violent. ${ }^{35}$

\section{III}

\section{Synopsis of the Spouse Abuse Literature}

The data summarized above are known to gun control theorists, having been provided by their own empirical investigations. It is not apparent to a family law specialist surveying this literature, however, that gun control opponents and proponents are acquainted with the evolving literature on spouse abuse. Again, full discussion of this literature is beyond the scope, and indeed the purpose, of this commentary, but a synopsis may demonstrate the pertinence of the spouse abuse literature to gun control issues.

Episodes of violence between spouses tend to increase over time in frequency and intensity. ${ }^{36}$ One study, conducted by the Kansas City Police Department in the early 1970's, confirms that domestic homicides tend to be preceded by domestic disputes. ${ }^{37}$ This study, which has assumed some prominence because it is believed to describe the prior violent history of domestic killers more accurately than arrest or conviction data, ${ }^{38}$ found a substantial history of marital discord in domestic homicide cases. In ninety percent of the cases, police had been called to that address at least once in the

32. Wolfgang categorized homicides as "violent" or "non-violent." The former included those involving two or more acts of stabbing or shooting, severe beating, and severe beating followed by one stab or shot. Id. at 159; see also I. Berg \& J. Fox, Factors in Homicides Committed by 200 .1/ales, $26 \mathrm{~J}$. Soc. Psychology 109, 111 (1947).

33. Id. at 214 .

34. Id. at 164 . Thirty-four $(65 \%)$ of the 52 homicides involving five or more acts of stabbing or shooting occurred in the home, although Wolfgang noted only an insignificant tendency for all violent homicides to occur in the home. Id.

35. Of 83 homicides resulting from domestic quarrels, $50(60 \%)$ were committed violently. Sep supra note 32. This proportion is equaled by homicides arising from robbery (24 of 40 ) and unknown circumstances ( 17 of 28 ), and is exceeded only by revenge homicides. Of the latter, $68 \%$ (21 of 31 ) were committed violently. See Wolfgang, supra note 1, at 195.

36. See, e.g., Walker, The Batlered Iloman Sydrome Study, in The Dark Side of Familifes: Current Famil.y Violence Research 31, 43 (1983) [hereinafter cited as Dark Side of Familif.s].

37. Id. at $207-08$.

38. Arrest records underestimate previous violent behavior because violent acts are underreported. The 1980 National Crime Survey found that spousal victimizations are not reported to the police $43 \%$ of the time. Berk, Berk, Loseke \& Rauma, Llutual Combat and Other lamily Iiolence

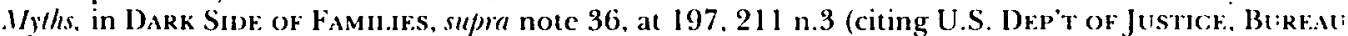
of Justicf Statistics, 1980 National. ('kime Survey). In addition, not all of the reported incidents result in an arrest. Records of prior conviction or imprisonment underestimate even further the level of past violent behavior, duc to case loss. Kleck \& Bordua, supra note 6, at 93-95; $f$. M. Wor.foixc;. sufmat note 1, at 174-75 (explaining reasons for using arrest rather than conviction data). 
preceding two years; in half of the cases, police had been called five times or more in the preceding two years. ${ }^{39}$ Spouse abuse, therefore, may be viewed as an early stage of cases that proceed to homicide, despite the fact that only a small percentage of abused or abusive spouses ever kill their mates. The spouse abuse literature is instructive whether the husband or the wife is the offender, but the etiology of the two cases is so different that they should be reviewed separately.

\section{A. Husbands as Offenders}

Like the blind men's descriptions of the elephant, explanations of why husbands abuse their wives ${ }^{40}$ are almost as numerous as the theorists

39. Fields, Wife Beating: Government Intervention Policies and Practices, in U.S. Comm'N ON CIVIL Rights, Battered Women: Issues of Public Policy 228, 246-47 (1978) (consultation sponsored by the United States Commission on Civil Rights) [hereinafter cited as BatTered Women].

40. While women have traditionally been considered the victims of spouse abuse, in the late 1970's sociologist Suzanne Steinmetz contended that husband-beating constitutes a sizeable proportion of family violence. Steinmetz, The Battered Husband Syndrome, 2 Victimology 499 (1978). Her allegation that wives are as violent toward husbands as husbands are toward wives, however, met with instantaneous and vigorous criticism. Leghorn, Response, in BATTERED WOMEN, supra note 39, at 444, 450-53; Pleck, Pleck, Grossman \& Bart, The Battered Data Syndrome: A Comment on Steinmetz'Article, 2 Victimology 680 (1978). The harsh criticism arose because, among other reasons, Steinmetz overlooked the context of the events. She had, for example, relied on Wolfgang's findings that wives and husbands kill each other in roughly equal proportions without noting his additional finding that women act in self-defense seven times more often than men. See A. Jones, Women Who KiLl 300-01 (1980); Pleck, Pleck, Grossman \& Bart, supra, at 682.

The mutual combat view of spouse abuse is grossly misleading. In fact, the vast majority of domestic violence cases involve battered women and children. In the Philadelphia domestic abuse clinic, for example, $95 \%$ of the clients are women even though the clinic was intended to serve both male and female abuse victims. Fain, Conjugal Violence: Legal and Psychosociological Remedies, 32 Syracuse L. Rev. 497, 544 (1981). National figures are similar. Jones, supra note 15, at 14. At least one group, the Illinois-based American Divorce Association of Men, disagrees with these statistics. Id. Nevertheless, during the first five months after enactment of the Illinois Domestic Violence Act, Ill. ANN Stat. ch. 40, $\S$ 2301-1 to 2403.1 (Smith-Hurd Supp. 1983-84), which protects abuse victims without regard to sex, only 20 of 880 protection orders $(2.3 \%)$ were issued on behalf of battered men. Jones, supra note 15 , at 14 .

Abuse complaints filed by men tend to "involve harassment, such as being locked out of their homes by their wives or being beaten by their children." Fain, supra at 544-45. Men who choose to stay in these situations do so in order to protect their children from their wives, Jones, supra note 15 , at 14, or because of inability to support two families and unwillingness to leave behind home improvements. Steinmetz, supra, at 506-07. This "abuse" experienced by men is qualitatively different from that experienced by women. See infra text accompanying notes 59-77.

When domestic violence occurs, wives are injured more often and more seriously than husbands. One study, based on police calls for "domestic disturbances," found that when injuries were reported, women were victims $94 \%$ of the time and men were victims $14 \%$ of the time (both were injured in $4 \%$ of the cases). Berk, Berk, Loseke \& Rauma, supra note 38, at 197, 199, 204. In $39 \%$ of the total number of cases, the woman was the only person injured; the man alone was injured in only $3 \%$ of the cases. Id. at 204. These researchers concluded that "if there is anything to the battered husband syndrome, it either has nothing to do with injuries or is relevant to very few couples." Id. The researchers also dismissed the view of domestic violence as mutual combat:

[W] hen injuries are one's primary concern, the mutual combat characterization of spousal violence is terribly misleading. "Mutual combat" calls up the image of Rocky Balboa and Apollo Creed going 15 rounds to a split decision. Nothing could be further from the truth. It is equally clear that if by the term "battery" one means assault with physical consequences, we can find no substantial evidence for the battered husband syndrome; our data show that it is amen who are battered. In this context, therefore, terms like "mutual combat" are at best imprecise, and while there are certainly occasional instances of husbands being battered, it is downright pernicious to 
proffering them. Although the body of literature taken together does not clearly resolve this crime-of-passion debate, all of the current ${ }^{41}$ theories reveal the complexity of social and psychological factors underlying wife abuse.

Some commentators have blamed battering on the "traditional" pattern of marriage, characterized by patriarchy and female dependency and passivity. ${ }^{42}$ Women are, in fact, abused most often in husband-dominated relationships and least often in relationships in which the partners follow an egalitarian pattern of decisionmaking. ${ }^{43}$ Both partners in so-called "traditional" relationships usually have been reared with strongly differentiated sex-role expectations. Men are often socialized to be dominant, aggressive, and even violent. $^{44}$ Masculinity itself becomes identified with these characteristics of strength and authority. On the other hand, women are often socialized to be passive, submissive, and dependent. ${ }^{45}$ When marital partners having these traditional views of male-female roles come together, the result is all too often an abusive relationship. ${ }^{46}$

A second sociological theory of wife abuse-the resource theory-has as its main hypothesis the premise that a person whose personal resources (such as income, job prestige, education, and community standing) are low, is likely to use physical power available to him to "lower the perceived status

equate their experiences with those of the enormous number of women who are routinely and severely victimized. In short, our analysis indicates that, at least when injuries are one's primary concern, spousal violence is about the harm that men inflict on women.

Id. at 210 (emphasis in original) (footnote omitted). In this article, "spouse abuse" means abuse of wives by their husbands.

41. The only theory that has been laid to rest is the psychopathological theory-that men who beat their wives are "psychotic" or suffering from some personality defect and their violent behavior is irrational. See A. Jones, supra note 40, at 307; Freeman, Violence Against Women: Does the Legal System Provide Solutions or Itself Constitute the Problem?, 7 BRIT. J.L. \& Soc'y 215, 215-18 (1980). Further study has indicated that homicide offenders in general have no greater tendency toward mental illness than the population at large. Straus, Wife Beating: Causes, Treatment, and Research Needs, in BATTERED Women, supra note 39 , at 463,515 . Thus, wife beaters are not clinically sick, and rejection of the illness model as an explanation of battering is, perhaps, the only point of agreement among current theorists. 216

42. See, e.g., Martin, Overview-Scope of the Problem, in Battered Women, supra note 39, at 205,

43. Murray Straus, one of the leading sociologists researching family violence, and his colleagues conducted a study of 2,143 randomly selected American families in the late 1970's, under a grant from the National Institute of Mental Health. Because the study sample was large and nationally representative, the study is one of the most important in this area. The researchers found, among other things, that less than three percent of wives in couples that followed an egalitarian pattern of decisionmaking had been violently attacked in the preceding year. Corresponding figures were $7.1 \%$ in wife-dominant couples and $10.7 \%$ in husband-dominant couples. Thus, the rate of wife beating in husband-dominant couples was $50 \%$ higher than for wife-dominant couples and over 300\% higher than for egalitarian couples. See M. Straus, R. Gelles \& S. Steinmetz, Behind Closed DOORS: Violence in THE AMERICAN Family 194 (1980).

44. Fain, supra note 40, at 510-12; Martin, supra note 42, at 216.

45. Fain, supra note 40, at 510-12; Martin, supra note 42, at 216.

46. [S/ex roles stereotyping and socialization in childhood is a major factor in determining the power relationships between men and women which allow battering behavior to take place. . .

T]he lessons little girls learn, to be nurturing, complaisant, and a good little passive wife: and the lessons that little boys learn, to be strong, aggressive, and the husband in charge. equally set the stage upon which which later violence gets played out.

Oral remarks of Lenore Walker at United States Commission on Civil Rights Consultation, Jan. 31. 1978, in BATTERF.D WOMEN, supra note 39, at 160, 161. 
difference." 47 Thus, a husband whose single resource, masculinity, is threatened by his wife is more likely to hit her than a husband whose selfimage is based upon multiple resources. Although this theory overlooks the fact that abuse is most prevalent in husband-dominated relationships, in which the man should have a higher level of personal resources, it is consistent with a University of Florida study that found that husbands "mostly killed their wives because of bruised egos." 48 These husbands responded to what they viewed as threats to their masculinity, so the researchers labeled these "sex-role-threat homicides." "A walkout, a demand, a threat of separation are taken by a man to represent intolerable desertion, rejection and abandonment." 49

The exchange and social control theories of wife abuse are compatible with the resource theory. According to the exchange theory, interactions between people generally break off if a reciprocal exchange of rewards is not achieved. But when interaction cannot simply be ended, as in family relationships, failure of expected rewards leads to anger and resentment. Violence may result if social controls are inadequate to prevent it and that, in turn, depends upon the costs attached to the violence. Spouses have a high potential for instigating violence between themselves for a number of reasons, ${ }^{50}$ and forces inhibiting that violence are generally weak. First, some level of violence between spouses is normatively accepted and acceptable, although this does not suggest that violence rising to the level of abuse is widely approved. ${ }^{51}$ Second, the potential for retaliation is low, given the

47. Walker, supra note 36, at 31, 39; see also Richette, Support Services: Long-Term Needs for Battered Women-Uinderpinnings to Decay or Foundations for New Structures?, in BATTERED WoMEN, supra note 39, at 409, 413. But see Berkowitz, The Goals of Aggression, in DARK Side of Families, supra note 36, at 166, 172 (criticizing a similar formulation as slighting "the important role of situational stresses in family violence').

48. Jones, supra note 15 , at 15 .

49. Id. The point of separation is also dangerous to husbands. See infra text accompanying notes 75-76; A. JonEs, supra note 40, at 298-99.

50. Hotaling and Straus have listed 11 reasons why families, contrary to their idealization as benevolent and loving relationships, are especially prone to violence: (1) length of time spent together; (2) range of shared activities; (3) greater intensity of involvement; (4) activities and habits that infringe on other members; (5) attempts to change other members, based on a perceived right to do so; (6) age and sex differences, with concomitant differences in perspectives; (7) ascription of roles on the basis of sex rather than competence and interest; $(8)$ nuclear structure without extended family members who could dampen spousal disputes; (9) involuntariness of spousal relationship, when leaving is not practical; (10) high level of stress due to major structural changes, caused by birth and maturation of children, aging and retirement; and (11) intimate knowledge of weaknesses and vulnerabilities. Hotaling \& Straus, Culture, Social Organization, and Irony in the Study of Family Fiolence, in The Social Causes of Husband-Wife Violence 3, $15-18$ (1980); see also Sebastian, Social Psychological Determinants, in DARK Side of FAmilies, supra note 36 , at 182.

51. One frequently cited finding is that of a now-dated Harris poll which reported that $20 \%$ of American adults approved of slapping one's spouse on "appropriate" occasions. Stark \& McEvoy, Middle-Class riolence. Psychology ToDar, Nov. 1970, at 52-53. Also cited are popular jokes and "mores and folkways which accept and even mandate the use of violence in families (such as . . . the English law 'rule of thumb' which gave husbands the right to strike their wives with sticks no larger than their thumbs)." Gelles, An Exchange/Social Control Theory, in Dark SIDE Of Families, supra note 36 , at 151.157 .

Better evidence is available from two studies of randomly selected samples. In the first. conducted by Straus and his colleagues, the researchers prepared a Physical Violence Index listing 
physical disadvantage at which wives find themselves and the general socialization of women toward passivity and nonviolence. Finally, the chances of arrest for spouse assault, much less conviction and imprisonment, are very low. ${ }^{52}$ Thus, a husband angered by frustrated expectations will experience few social controls inhibiting violent expression of that anger.

The learning theory of spouse abuse notes that the almost universal characteristic in the background of both wife batterers and wife killers is a history of abuse, either as victim or witness. ${ }^{53}$ Violence, therefore, is a learned response pattern. ${ }^{54}$ The husband who abuses his wife is merely playing out the models he has seen and experienced.

A final theory of wife abuse-the expressive violence theory-is much more controversial. This theory postulates that inflicting pain or injury on a perceived provocateur ${ }^{55}$ can be psychologically rewarding. The goal may not be to control the spouse's behavior or to rectify a perceived imbalance, but to inflict pain and injury in itself:

[I]f the situation is right, if inhibitions against aggression are weak and there is a suitable target, the aversively instigated aggression can be translated into open violence. What we then see is emotional aggression. All aggression is not carried out in the heat of intense feelings. A good deal, especially instrumental aggression, can be coolly calculating. But just as it is a mistake to deny this instrumental behavior, so is it also wrong to neglect the emotional, aversively stimulated aggression, as some analyses have done.

. . . This may not be apparent to those who are thinking only of instrumental aggression carried out in pursuit of noninjurious ends, such as social status, approval, or ego-enhancement. ... [A]versively stimulated aggression often pursues a particular objective, the inflicting of injury. ${ }^{56}$

eight acts: (1) throwing things at the spouse; (2) pushing, shoving, or grabbing; (3) slapping; (4) kicking, biting, or hitting with the fist; (5) hitting or trying to hit with something; (6) beating up; (7) threatening with a knife or gun; (8) and using a knife or gun. The researchers defined wife beating as incidents including one or more of the last five acts on their list. They found that some violent act had been committed by the husband during the previous year in 12\% of the marriages; wife beating had occurred in nearly 4\%. See M. Straus, R. Gelles \& S. Steinmetz, supra note 43, at 36, 40.

Greenblat interviewed a randomly selected sample of men and women in the early years of marriage to determine the extent to which a cultural norm approving family violence exists. She found that the subjects adamantly disapproved of spouses hitting each other as the exercise of a legitimate right, but that considerable tolerance for hitting was implicit in the subjects' responses. Greenblat, A Hit Is a Hit Is a Hit . . . Or Is It?: Approval and Tolerance of the L'se of Physical Force by Spouses, in Dark Side of Families, supra note 36, at 235, 255.

52. The failure of police to arrest, and of prosecutors to prosecute, spouse abusers is notorious. See, e.g., Thurman v. City of Torrington, 595 F. Supp. 1521 (D. Conn. 1984); Bruno v. Codd, 47 N.Y.2d 582, 393 N.E.2d 976 (1979).

53. See Fain, supra note 40, at 516-17.

54. See, e.g., Fagan, Stewart \& Hansen, Violent Men or Tiolent Husbands?: Background Factors and Situational Correlates, in DARK SIDE of FAmilies, supra note 36, at 49; Walker, supra note 36, at 32; Walker, Thyfault \& Browne, Beyond the Juror's Ken: Battered llomen, 7 VT. L. Rev. 1 (1982). But see Herrenkohl, Herrenkohl \& Toedter, Perspectives on the Intergenerational Transmission of Abuse, in DARK Side of Families, supra note 36 , at 305.

55. Perception of provocation is the important element, since no provocation may objectively exist. This theory, therefore, does not carry an inference that abused wives are necessarily responsible for the abuse. See Sebastian, supra note 50, at 186; see also infin text accompanying notes 66-69.

56. Berkowitz, supra note 47 , at 175. 
The evidence for this position is mixed, and thus not all researchers support the expressive violence analysis. ${ }^{57}$ Those who disagree argue that this so-called "out-of-control" theory is a convenient excuse for explaining away otherwise unacceptable behavior:

Actors tend to be deterred. . . from violent actions to the extent they believe they will be unsuccessful. If there is no critical audience and if the costs of failure are low (police and courts are unlikely to respond with serious sanctions, wives have no place to go and obtain little sympathy from others), the violent outburst is more likely. Then it may be neutralized with an "out-of-control" explanation. 58

\section{B. Wives as Offenders}

Approximately half of spousal homicide offenders are wives. These murders cannot be explained as spouse abuse gone too far, however, since serious spouse abusers are generally husbands rather than wives. Spouse abuse is a factor nevertheless, because once a domestic dispute escalates to a potentially lethal level, the wife often kills in self-defense. ${ }^{59}$

Wolfgang did not discuss self-defense homicides, but termed "victimprecipitated" those criminal homicides in which the victim was the first to use physical force by showing and using a deadly weapon or by striking a blow. ${ }^{60}$ He found that of the forty-seven husbands killed by their wives, twenty-eight, or nearly sixty percent, of the victims precipitated their own deaths. Conversely, only nine percent of the wife slayings were victim-precipitated. ${ }^{61}$

57. Id. at 189 .

58. Greenblat, supra note 51 , at 257.

59. In this article, the term "self-defense" is not used in the technical sense of a legal defense to a criminal charge. Although women who kill their husbands may be acting out of perceived selfdefense, they may not be able to establish the technical requirements for a legal defense of selfdefense: that the wife was a nonaggressor who reasonably believed herself in immediate danger of death or serious bodily harm and that the use of force was necessary to avoid the danger. See generally W. LaFave \& A. Scott, Handbook on Criminal Law 391-97 (1972).

The legal defense may fail for several reasons. First, a woman may counter her husband's clinched fist with a deadly weapon, since her size and strength disadvantages may make unarmed defense impossible. (Note that in none of Wolfgang's or the 1967 survey's cases did the wife kill the husband without use of a weapon.) The legal defense will be lost, however, if she is viewed as having countered with force disproportionate to the threat. Second, because of the size and strength disadvantages, a woman who is not able to fend off her husband's beating may, in order to prevent future beatings, attack him after the episode is over and his attention is turned. Even though beatings are almost certain to recur otherwise, she cannot reasonably have believed herself to have been in imminent danger of death or serious bodily harm, as required by the law of self-defense. Thus, a woman who heated water following a beating and poured it over her then-sleeping husband could not establish self-defense for the fatal scalding. Stout, Response, in Battered Women, supra note 39 , at 288,298 . Third, a prominent psychologist has found that a wife, recognizing the building tension and the inevitability of a violent episode. may provoke the incident in order to get it over with. Martin, supra note 42, at 206 (citing Walker, The Battered Woman Syndrome Revisited: Psychosocial Theories 5 (paper presented at the American Psychological Association Annual Meeting, San Francisco, California, Aug. 29, 1977)). If the violent episode results in her husband's death, however, the wife may be characterized as the attacker rather than a would-be victim who acted in self-defense.

60. M. WolfGang, supra note 1 , at 252 .

61. Id. at 260 . Contrast these figures with Wolfgang's finding that 43 of the 88 cases in which a woman killed a man were victim-precipitated. Id. at 259.

Despite these figures, Wolfgang probably understated the incidence of self-defense by focusing on criminal homicides and excluding justifiable and excusable homicides. He defined as criminal 
Wolfgang concluded on the basis of these findings that police should "thoroughly investigate every possibility of strong provocation by the male victim when he is slain by a female-and particularly . . . if the female is his wife."'62

More recent studies are consistent with Wolfgang's finding that wives who kill their husbands have been strongly provoked. These studies confirm that wives often kill in self-defense and that they have frequently been abused. University of Florida researchers found that most of the women studied who had killed their husbands did so "only after being subjected to prolonged physical or verbal abuse."63 A study of women held in the Cook County, Illinois jail on charges of killing their male partners found that forty percent had been abused by their victims. ${ }^{64}$ These studies and others with similar findings ${ }^{65}$ demonstrate that wife abuse jeopardizes the lives of husbands as well as wives.

Abused wives frequently tolerate the abuse, at least initially, because they often believe that they are somehow to blame for their predicament. ${ }^{66}$ This

homicides "[a]ll slayings not recognized as justifiable, accidental, or excusable by the police and the coroner's inquest, and that normally make, or would make, a suspect subject to arrest and prosecution." Id. at 16 . Of the 625 homicides examined, $37(6 \%)$ were noncriminal, including 23 excusable or accidental killings and 14 justifiable killings. Id. at 24 . If these cases were included in the analysis, therefore, a higher proportion of the total would be expected to involve self-defense. Nonetheless, Wolfgang found that in 38 of the 47 spousal homicide cases in which the husband was killed, he had "strongly provoked" his wife's attack "and, although she was not exonerated on grounds of self-defense, there had been sufficient provocation by the husband (as the victim) to reduce the seriousness of her offense. In contrast, provocation recognized by the courts occurred in only five cases in which husbands killed their wives." Id. at 217.

Wolfgang did not conclude that courts were more lenient toward wives, despite finding that husbands were more likely to be found guilty than wives and that husbands who were convicted were convicted of more serious offenses than wives who were convicted: $64 \%$ of husbands and $55 \%$ of wives were found guilty while $34 \%$ of wives but only $4 \%$ of husbands were acquitted; more than half of the husbands were convicted of murder, while over $80 \%$ of the wives were convicted of manslaughter; one-third of the husbands, but no wives, were convicted of first degree murder. Id. at 217. But see Jones, supra note 15, at 51 (reporting a 1979 Minnesota study that found "higher conviction rates and stiffer sentences for women than for men accused of homicide" and attributing this change to a backlash against "resurgent feminism").

62. M. WOlfGanG, supra note 1 , at 259 .

63. Jones, supra note 15 , at 15.

64. Study of Female Killers Finds t0\% Were Abused, N.Y. Times, Dec. 20, 1977, at 20, col. 8.

65. A study of inmates at California's Institution for Women found that in $22 \%$ of the cases for which the homicide offender's rationale was known, she claimed self-defense or defense of others. See Ward, Jackson \& Ward, supra note 15 , at 872 . The $22 \%$ figure underestimates the total number of homicides in which women killed in self-defense because it does not account for cases in which the offender was not prosecuted, was acquitted, or was given a penalty other than incarceration.

The 1967 survey found that males often precipitate their own deachs. Forty-six percent of homicides in which males were victims and in which the presence or absence of victim precipitation was known were victim-precipitated. The corresponding figure for females was $17 \%$. Sep D. Mulvihill, M. Tumin \& L. Curtis, supra note 2, at 321 . Of the 48 husband-wife homicides for which the presence or absence of victim precipitation was known, $29(62 \%)$ were victim-precipitated. Spe id. at 331. Unfortunately, the survey did not further refine that figure to reveal the pcrcentage of husbands as opposed to wives who precipitated their own deaths.

66. Oral remarks of Elaine Hilberman at United States Commission on Civil Rights Consultation, Jan. 31, 1978, in BATTEREd WOMEN, supra note 39, at $157,159$. 
notion, which is widely shared by society in general ${ }^{67}$ and is even a frequent, although subtle, element in the spouse abuse literature, ${ }^{68}$ disables women from taking affirmative steps to leave the abusive situation. Only after concerted efforts to be completely noninstigational through total passivity may a woman realize that triggering events are nonexistent or extremely trivial ("she wore her hair in a ponytail; she prepared a casserole instead of fresh meat for dinner; she said she did not like the pattern on the wallpaper") 69

Abused wives also feel compelled to remain in the relationship because of the pattern it typically follows. Leonore Walker, a psychologist prominent in

67. When Greenblat asked her respondents to list circumstances in which a husband might hit his wife, she found that " $[\mathrm{t}] \mathrm{he}$ victim's behavior . . . is the major reason listed by both the male and female respondents here, though the men are more likely than the women to have pointed to her precipitating actions as the basis of his hitting." Greenblat, supra note 51, at 244. Interestingly, when Greenblat asked for circumstances in which a wife might hit her husband, she found that

for both male and female respondents, the modal explanation is the hitter's feelings, rather than the victim's provocative behavior. In other words, when women are HIT, they are often described as responsible; when women HIT, again they are responsible. THUS, IT IS NOT A SIMPLE CASE OF BLAMING THE VICTIM, BUT OF BLAMING THE FEMALE.

Id. at 245 (emphasis and capitalization in original).

68. In the context of traditional views of masculine and feminine roles, for example, women are in a no-win situation:

If a woman has more education, earns more money, or has more power in the community than her husband, she does not conform to the accepted feminine model. This may threaten the husband's masculinity, thus producing frustration that may lead to stress and abuse Conversely, if the woman has very traditional views regarding male and female sex roles, she may feel that earning more money and having more education are not feminine. Thus, she may submit to psychological or physical abuse.

Fain, supra note 40, at 511-12. Thus, the untraditional woman provokes attack and the traditional woman accepts it. Either way she is to blame.

The resource theory of spouse abuse, see supra text accompanying notes 47-49, also has a strong victim-blaming tendency. The theory not only overlooks the fact that abuse is most prevalent in husband-dominant relationships, see supra note 43 , but also creates another no-win situation for the wife:

The problem with this theory is that, as the copious literature on gender stratification implies. families in which she outscores him in status are very rare. . . . In fact, researchers do not find such families. Nor, of course, do they abandon the personal resource theory. What they do instead is change the operational definition of "wife-dominant/wife-superior" so that it is a contest the husband can lose. Thus, he may be compared to her on a variety of dimensions, and if he loses on one-any one-she wears the pants in the family, even if he wins on the rest. Or he may be compared not to her but to her father. Or he mav be compared to her expectations of what an ideal husband should be: If he falls short in her mind, it becomes stressful and he hits her. Or the deficient husband may be compared to his own expectations of what an ideal husband or ideal man should be. (Notice, incidentally, that earlier we learned if she falls short of his expectations concerning perfect wives, that's stressful and he hits her. In other words, if anyone falls short of anyone's expectations, it's all her fault and we can see why he hits her.) Or. finally, if no comparison within the relationship shows him henpecked, the analysis can move outside the relationship and contrast him to other men. If he has less resources than ther, or less power over her than they have over their wives, we mav conclude that there is a personal resource imbalance in her favor after all, and he is using violence to right the scales.

Wardell, Gillespic \& Leffler, Science and Violence Against II ives, in Dark SIDE OF Familif.s, supra note 36. at 69,77 (footnotes and citations omitted).

Walker rejects victim-blaming explanations of spouse abuse. "Our data confirm that domestic violence does not come from the interaction of the partners in the relationship. or from provocation from irritating personality traits of the battered women, but rather from the battercrs lcarned behavioral responses." Walker, supra note 36 , at 37.

69. Martin, supra note 42 , at 214 . 
spouse abuse research, has isolated this pattern and labeled it the "cycle theory of violence." Domestic violence episodes tend to have three stages, according to Walker: the building of tension, the violence itself, and a period of "loving contrition," characterized by tenderness and caring. ${ }^{70}$ Walker has called the third stage "the insidious victimization part," 71 because the woman refuses to give up the relationship, hoping instead "that somehow she'll do something better to make those periods of love be longer and longer and longer, and the period of violence shorter."72 The opposite is the case, however: the periods of tension-building and violence become longer while the period of loving contrition grows shorter. ${ }^{73}$ Walker found that the woman is more likely to leave the relationship once the rate of positive reinforcement decreases. ${ }^{74}$

The point of separation, once reached, is risky for both spouses. It poses such a threat of abandonment that a husband may kill his wife rather than let her go, ${ }^{75}$ but the husband who attempts to prevent his wife's departure may jeopardize his own life:

We found that usually the women who turned on their mate[s] during an attempt to
escape, never intended to kill them, only to prevent them from blocking their escape
or from hurting them again. Most of these women did not have a history of violent
behavior, and, for most, it was the first time they had fought back against their
batterer. Nearly all called the police and an ambulance at once, and did not realize
they had critically wounded him until they were informed later that he was dead. This
is consistent with the findings of others that women who kill are seven times more
likely to be motivated by self-defense than are men. ${ }^{76}$

Similarly, Dr. Elaine Hilberman, a psychiatrist who treats abused women, reported that her patients exhibited a uniform psychological response to their experiences that she described as "paralyzing terror." Dr. Hilberman also noted that battered women build up high levels of anger but they

rarely experience their anger directly, although their stories elicited despair and
outrage in the listeners. Aggression was most consistently directed against themselves
with suicidal behavior, grotesque self-images, alcoholism in a few, and self-mutilation
in one woman. . . Passivity and denial of anger do not imply that the battered
woman is adjusted to or likes the situation. It is the last defense against homicidal rage.

Thus, wives who kill their husbands often have been abused to the point that they finally act to stop the beatings by fighting back or by killing husbands who bar their exit. They are frightened and desperate women.

70. Walker, supra note 36 , at 43 .

71. Oral remarks of Lenore Walker, supra note 46 , at 169.

72. Id.

73. Id.

74. Walker, supra note 36 , at 44 . Walker found that, for first incidents, the tension-building and loving contrition phases were present in $50 \%$ and $69 \%$ of the cases respectively. By the time of the last battering incident, $71 \%$ were preceded by a tension-building phase. but loving contrition followed in only $42 \%$. Id.

75. Walker, Thyfault \& Browne, supra note 54, at 12.

76. Id.; see also supra text accompanying note 49 .

77. Oral remarks of Elaine Hilberman, supra note 66 , at 159 (emphasis added). 


\section{Lessons for Gun Control Drawn from the Spouse Abuse Literature}

The last task is to draw connections between the spouse abuse literature and those propositions around which much of the gun control debate centers. This article can only provide suggestions; further evaluation by gun control empiricists is clearly necessary to test whether incidents of spouse abuse may be affected by gun control measures.

As the reader will recall, the first basic proposition central to proponents of gun control is that spousal killers are acting under a spontaneous murderous rage and, therefore, that such killings are crimes of passion. If this proposition is accurate, gun control measures that remove firearms from easy reach may have an ameliorative effect on the homicide rate. If spousal homicides derive from a determination ${ }^{78}$ to kill, ${ }^{79}$ however, offenders may be expected to obtain guns illegally, if necessary, in order to carry out the desired killing.

The prior history of violence of homicide offenders generally ${ }^{80}$ provides some support for the proposition that all killings involve a desire to kill and that efforts are repeatedly made until that desire is accomplished. ${ }^{81}$ The vital link between these data for homicide offenders overall and their application to spouse killers ${ }^{82}$ is provided by the previously mentioned Kansas City study which found a pattern of police calls preceding domestic killings. ${ }^{83}$ This prior history of violence leads some prominent commentators in the gun control field to conclude that "the average murderer," which presumably includes the

78. The term "intent" is deliberately avoided here so as not to suggest that these homicides are premeditated in the first-degree murder sense.

79. Characterizing the debate as polar positions dramatizes it for discussion but obscures some of the complexity. The truth may lie somewhere between these positions. Professor Zimring, for example, asserted that "many homicides are related to variable states of intention and ... a significant proportion do not result from an attack committed with the single-minded intention to kill." Zimring, supra note 6, at 724. But see Hardy \& Stompoly, supra note 4, at 104-05.

80. The typical homicide offender has a history of violating the law. One pair of commentators has estimated-conservatively, they claim-that the majority of homicide arrestees have prior arrest records, that half of them have prior convictions, and that a fourth of them have prior felony convictions. Kleck \& Bordua, supra note 6, at 95. Washington, D.C. homicide data from 1966-1967 indicate that the typical homicide offender "has been arrested previously six times, twice for serious crimes, including once for a crime of violence." Kates, Criminological Perspectives on Gun Control and Gun Prohibition Legislation, in Why Handgun Bans Can'T Work 3, 25 (D. Kates ed. 1982). Sixtv-four percent of the offenders in Wolfgang's sample had a previous arrest record and, of those with a record, $66 \%$ had been arrested for an offense against a person. M. WolfGANG, supra note 1 , at 175 . 178. (Wolfgang also found that a large proportion of victims-47\%-had previous arrest records.) Nationwide, two-thirds of those arrested for murder or nonnegligent manslaughter from 1970 to 1975 had prior arrest records. Kleck \& Bordua, supra note 6, at 94.

81. See Kates, supra note 80, at 25-26.

82. Data for all homicide offenders may not accurately describe that small proportion of such offenders who have killed a spouse. Thus, findings based on homicide offenders generally should not be applied to spouse killers in a cavalier fashion. Research is needed on the question whether. and in what ways, spouse killers differ from homicide offenders generally.

83. See supra text accompanying notes 37-39. 
average spouse murderer, "turns out to be no less hardened a criminal than the average robber or burglar." 84

Wright and Rossi also cite the Kansas City study as support for the hypothesis

that much domestic homicide is not an isolated occurrence or outbreak, but rather is the culminating event in a pattern of interpersonal abuse, hatred, and violence that stretches back well into the history of the parties involved . . . . The point, of course, is that the a priori intentionality in many cases of domestic homicide is not going to be nearly as ambiguous as it is depicted in the typical account. ${ }^{85}$

The above assessment is consistent with data demonstrating that spouse abuse is cyclical and escalates in frequency and intensity. This series of increasingly violent attacks, culminating in homicide, is certainly interpretable as expressing a progressively more lethal intent by the perpetrator, an intent resulting in death when the determination to kill becomes strong enough.

The Wright and Rossi assessment overlooks, however, that the Kansas City study does not indicate which spouse's violence resulted in the police call. $^{86}$ The spouse abuse literature teaches that it is husbands who assault their wives. Wives who kill their husbands typically have no history of criminal or violent behavior. Thus, the spouse abuse data require further refinement of Wright and Rossi's argument to make it apply to husbandoffenders alone, who constitute only slightly more than half of all spousal killings. The Kansas City study's demonstration that domestic disturbances precede domestic homicides, coupled with the established fact that husbands abuse wives (and not vice versa), ${ }^{87}$ suggests that the history of violence documented in Kansas City is a husband-perpetrated pattern. Consequently, the study probably says little about the propensity toward violence or "a priori intentionality" of wife-offenders.

The fact that domestic violence is husband-perpetrated, however, does not establish the opposite conclusion-that wife-offenders do not intend to kill, but are acting in the heat of the moment. These women may have "premeditated" to the extent of thinking about killing their husbands. Indeed, it is difficult to imagine that a seriously abused wife would not have entertained such thoughts at some time. These thoughts may additionally have led her to obtain the weapon with which to accomplish the act (at least in the case of a gun, since knives are readily available), should her husband ever assault her again (which the spouse abuse literature tells us he will). The point here is merely that the Kansas City study tells us nothing about these cases.

The spouse abuse literature more fully reveals the motivations of wifeoffenders. Wives suffering from the spouse abuse syndrome tend to blame

84. Kates, supra note 80 , at 26 . Kates further concluded that "[s]ince even the advocaltes of handgun prohibition will generally concede that the ban will not disarm robbers and burglars, there is little reason to think it will disarm murderers either." Id.

85. J. Wright, P. Rossi \& K. DALy, supra note 6, at 193 n.3.

86. Martin, supra note 42 , at 206.

87. See supra note 40. 
themselves for their situations and tend to be submissive to dominant husbands. Such women appear to kill out of great desperation, finally fighting back to protect themselves or striking out at husbands who bar their efforts to escape. Their intent is, apparently, not to kill but to protect themselves or to escape even at the price of killing. The psychological evidence is certainly not conclusive, nor is it totally inconsistent with a theory that these women formed an intent to kill and finally executed that intent. Rather, this evidence is another bit of data that should be considered in the gun control debate.

While psychological theories about husband-offenders should also be considered by gun control proponents and opponents, these theories are so diverse that they offer even less in the way of conclusions than does the literature relevant to wife-offenders. Most of those theories-specifically, the resource, exchange, social control, and learning theories ${ }^{88}$-point in no certain direction in the crime-of-passion debate. These theories reveal the complexity of social and psychological factors underlying wife abuse, which may itself indicate a likelihood that abusive husbands are not in control of their actions. On the other hand, the theories provide no reason to believe that husbands laboring under the psychological influences the theories describe are not also forming an intent to kill.

The "expressive violence theory" 89 is the psychological explanation of husband-offenders most relevant to the crime-of-passion debate. The theory, which postulates that inflicting pain is in itself psychologically rewarding, may point more readily to the view that spouse killers are emotionally out of control. The theory is also consistent with the fact that domestic violence escalates in frequency and intensity with the passage of time. As previously noted, however, the expressive violence theory is controversial. If the "outof-control" theory merely provides an acceptable excuse for otherwise unacceptable behavior, the perpetrator appears more calculating than is consistent with a crime-of-passion formulation. Furthermore, if the offender's psychological reward is based on infliction of pain, his "intent" is to inflict that pain rather than to kill. Use of a gun seems less consistent with the former intention than with the latter; greater pain would result from inflicting injuries that do not kill the victim, and fists or weapons other than guns seem more appropriate to the task.

If abusers are carrying out expressive aggression, motivated by anger, they are "out of control" and any resulting homicide may be described as a crime of passion. The out-of-control theory, however, does not necessitate a conclusion that these individuals are beyond the influence of all inhibitors. An aggressor may be moved by rage without being oblivious to external factors that, once perceived, change the calculus and inhibit violent expression of the anger. Thus, expressive aggression is not the end-all interpretation of an aggressor's actions.

88. See supra text accompanying notes 47-54.

89. See supra text accompanying notes 55-58. 
This interpretation seems more reasonable than a coldly calculated costbenefit analysis on the part of the perpetrator, later neutralized by "I couldn't help myself," because all of the theories explaining spouse abuse demonstrate the complexity of underlying sociological and psychological processes. Although the husband may realize that the physical violence with which he retaliates against threats to his masculinity is severe enough to be lethal, processes explaining his behavior are too complex to be reduced to a conscious, "unambiguous"9o intent to kill. This psychological evidence, again, is not conclusive, but it provides support for the argument that advocates of the crime-of-passion position are more likely correct than are "determinists" when analyzing cases in which husbands kill their wives.

The second basic proposition central to proponents of gun control is that spouse killers either would not substitute another weapon if they were deprived of guns ${ }^{91}$ or would substitute a weapon less lethal than a gun. Whether gun controls could ultimately reduce the rate of domestic homicide thus depends on whether a weapon is substituted, what weapon is substituted, and whether the substituted weapon is more or less lethal than the firearm that otherwise would have been used. Much has been written on the questions of substitution and comparative lethality, ${ }^{92}$ and this writer entertains no illusions about settling the questions. The debate can, however, be focused on the context of spousal homicide.

Although some writers assert that weapons substitution does not occur, ${ }^{93}$ most commentators believe that some other weapon will be utilized in place of the firearm rendered unavailable through an across-the-board ban. Wolfgang took an absolutist stance, speculating that "a gun is used because it is in the offender's possession at the time of incitement, but that if it were not present, he would use a knife to stab, or fists to beat his victim to death." Wolfgang recognized, however, that "the small physical size of the offender

90. Professor Zimring's argument that most homicides do not result from a single-ninded or "unambiguous" intention to kill is well-known. Zimring, supra note 6, at 726. His argument has been subjected to strong criticism. See J. WRIGHT, P. Rossi \& K. DALY, supra note 6, at 191-97; Hardy \& Stompoly, supra note 4, at 103-10; Kates, supra note 5, at 17-20.

91. Although investigation of this point is beyond the scope of this article, the entire gun control debate may turn on this proposition. Several writers have expressed considerable doubt that gum control measures will take guns out of the hands of persons likely to misuse them. Spe, e.g. Hardy. supra note 25, at 241-43; Kaplan, Controlling Firearms, 28 CLEv. ST. L. Rev. 1, $7-16$ (1979): Murrav. Handguns, Gun Control Laws and Firearm Violence, 23 Soc. Probs. 81 , 90 (1975); spe also Kleck \& Bordua. supra note 6, at 86-87 (begging the question whether gun control can remove guns from the violenceprone by concluding in the negative that "everyone who commits a homicide is by definition violence-prone"). But cf. Beha, supra note 5, at 129-32, 293-94 (finding increased compliance with licensing requirements under Massachusetts law prohibiting the carrying of a gun without a permit and imposing a mandatory minimum sentence).

92. See, e.g., Nat'l Comm'n on the Causes and Prevention of Violence, To Establisu Jis'ici.. To Insure Domestic Tranquility 17 (1970) [hereinafter cited as Eisenhower Comin RirorT: Fields, Handgun Prohibition and Social Necessity, 23 ST. Lours U.L.J. 35, 53-56 (1979): Scilz. Firparms. Homicides, and Gun Control Effectiveness, 6 LAw \& Soc'v REv. 595. 595-98 (1972). Bul spe Hardy \& Stompoly, supra note 4, at 102-03 (challenging Seitz).

93. See generally Eisenhower Comm'n RePort, supra note 92, at 17; Fields, supra nole 92. al 53 56; Seitz, supra note 92, at 595-98. But see Hardy \& Stompoly, supra note 4, at 102-03.

94. M. WOLfGanG, supra note 1 . at 79. 
relative to that of his potential victim, or the offender's physical repugnance to engaging in direct physical assault by cutting or stabbing his adversary, may mean that in the absence of a firearm no homicide occurs." 95 The utility of a gun in overcoming the disadvantages inherent in the use of knives or fists as weapons is particularly important in spousal homicides where, by definition, one party is a female who is probably smaller and weaker than the other party. Perhaps persons who would use a gun would be "too squeamish" 96 to use a knife or "psychologically unable to overpower their victim through violent physical contact." 97 Females in particular may have more difficulty due to traditional socialization. The bottom line, however, is that "there is no real evidence to suggest that it is easier, psychologically" for any person, male or female, to shoot another person "than to stab or bludgeon him" or her. ${ }^{98}$

Realistically, though, for a woman a gun is indisputably a great equalizer of physical strength. Wives have used knives to kill their husbands ${ }^{99}$ and, if guns were unavailable, some number of husbands would undoubtedly continue to succumb to knives wielded by their wives. Use of a knife rather than a gun, however, exposes the wife to a greater risk of successful resistance by the would-be victim because she typically must approach to within an arms-length distance. ${ }^{100}$ Thus, one conclusion to be drawn from a prohibition on firearms is that a homicide might be avoided that would have occurred if the wife had been armed with a gun.

On the other hand, remembering that the wife frequently kills in selfdefense, removing the gun from her hand and replacing it with a knife might render her defense ineffectual, with the result that the husband becomes the homicide offender rather than the victim. No net gain in terms of social policy results unless society is prepared to engage in an evaluation of the relative worth of lives. Some writers may do just that, ${ }^{101}$ but the enterprise carries a rational repugnance along with its frank emotional appeal.

In sum, gun control legislation banning all firearms, if enforced, probably would reduce the incidence of spousal homicide because some spouses (most likely wives) would not substitute knives or other weapons and, if knives were

\footnotetext{
95. Id.

96. Benenson, 4 Controlled Look at Gun Control, 14 N.Y.L.F. 718, 727 (1968).

97. G. NewTon \& F. ZimRing, supra note 6 , at 40.

98. Benenson, supra note 96 , at 727 .

99. See supra text accompanying notes $12 \& 14$.

100. She might instead throw the knife, see Fields, supra note 92 , at 47 , but one may safely assume such cases are unusual. Kates has argued that "the average person is simply not going to be able to defend himself effectively against an attacker wielding a butcher knife, ice pick or machete." Kates, supra note 5 , at 17 . The average man, however, should be able, with his greater reach, to resist the knife-wielding average woman by grabbing her arm-unless he is caught off-guard or intoxicated. (Alcohol or drug use often is involved when husbands beat their wives and when battered wives kill their husbands. Walker, Thyfault, and Browne found that three-fourths of the men in the homicide cases they studied were frequently intoxicated. Walker, Thyfault \& Browne, suprn note 54, at 10.)

101. Some feminists oppose gun control on the ground that it will remove the woman's equalizer and disable her from killing an abusive husband. Fields, for example, came close to this position when she wrote of society's "obligation to make this type of murder umecessary and to make the alternative of escape possible and rewarding." Fields, supra note 39, at 266 (emphasis added). Her implication that these murders currently are necessary clearly devalues life.
} 
substituted by wives, at least some husbands could successfully defend against the attack. Husbands, due to size and strength advantages, do not need weapons to kill, although some husbands who might have used a firearm might not turn to knives or fists. An across-the-board firearms ban, therefore, might save some lives, but this possibility rests upon a great deal of speculation.

If gun control legislation banning only handguns ${ }^{102}$ were adopted and enforced, some number of homicide offenders would undoubtedly substitute other weapons for the handguns they otherwise would have used. If they are hunters or persons committed to ownership of a firearm for self-protection, one of the available alternative weapons probably will be a rifle or shotgun, ${ }^{103}$ each of which is more lethal than both handguns and knives. ${ }^{104}$ Part of the substitution debate, therefore, centers around the percentage of offenders who will substitute long guns and the percentage that will reach for knives.

As important as the substitution rates are in determining gun control policy, little is known and much is guessed on this issue generally. (Estimates on the percentage of assaults in which long guns rather than knives would be substituted for handguns range from a low of thirty-three percent to a high of seventy-five percent. ${ }^{105}$ ) In the narrower context of spousal homicide, uncertainty is even greater. Concealability is not a factor weighing against the substitution of a long gun since spousal homicides usually occur in the home;

102. Banning all firearms, long guns as well as handguns, is neither politically feasible nor likely to gain public compliance. See Hardy, supra note 25, at 242. Registration, the other major gun control scheme, would have no impact on spousal homicide. "Mere registration would not deter those who kill in a fit of rage, for those individuals usually kill without consideration of the probability of detection." Hardy \& Stompoly, supra note 4, at 94 n.181. Furthermore, registration would not help locate otherwise unknown perpetrators. "As far as the basically law-abiding owner is concerned, his gun crime is most likely to be the shooting of a relative or acquaintance in the heat of passion. In these cases, the police usually find both the gun and its owner quite easily." Kaplan, supra note 91 , at 18-19.

103. Kleck \& Bordua, supra note 6 , at 80 . Apparently, even criminals originally acquire their guns for noncriminal purposes. Fields, supra note 92, at 42; Hardy \& Stompoly, supra note 4, at 101 n.228.

104. Professor Zimring's Chicago study was the first to compare the relative lethality of firearms and knives. Zimring concluded that guns are five times as lethal as knives, based on the rate of knife deaths per 100 reported knife attacks compared with the rate of gun deaths per 100 reported gun attacks. Zimring, supra note 6 , at 728 . Even when he assumed that only knife puncture wounds in vital body areas were attacks in earnest but that all gunshot attacks were in earnest, Zimring still found a death rate for gun attacks two and one-half times that for knife attacks. Id. at 734-35; see also Zimring, Games with Guns and Statistics, 1968 Wis. L. Rev. 1113, 1117 . Zimring's work has been severely criticized, however. See J. Wright, P. Rossi \& K. DALY, supre note 6, at 191-97; Hardy \& Stompoly, supra note 4, at 103-10; Kates, supra note 5, at 17-20; Kleck \& Bordua, supra note 6, at 8182.

The survival rate for victims of handgun attacks is approximately $85 \%-90 \%$. D. KATES, THE Sfcond Amfndment: Second to None 10 (Second Amendment Foundation Monograph Series 1982); Kates, supra note 80 , at 33 . This rate is only slightly lower than the survival rate for victims with penetrating abdominal wounds inflicted by ice picks or butcher knives. Kates, supra note 5 . at 18. Long guns, especially shotguns, are much more lethal. Hardy \& Stompoly, supra note 4, at 112 : Kates, supra note 80 , at 33,36 .

105. Kates, supra note 80, at 33-34. Using the low estimate, firearm homicides would double: using the high estimate, they would quadruple. Id. 
nor is the long gun's greater potential range a factor in its favor since these homicides usually occur at close range. ${ }^{106}$

Data indicating that weapons usage varies by the place within the home at which the homicide occurs, ${ }^{107}$ but does not vary according to the circumstances precipitating the attack, ${ }^{108}$ suggest that angry spouses use the nearest weapon. Perhaps most illuminating is the fact that the percentages of all murders committed with rifles and with shotguns have each varied no more than two percentage points in the last seventeen years. ${ }^{109}$ The percentages remained remarkably steady despite an increasing murder rate; 110 despite fluctuations in the percentages of all murders committed with every other type of weapon-handguns, knives and other sharp instruments, fists, and other miscellaneous weapons; ${ }^{11}$ and despite the vastly greater availability of long guns as compared with handguns. ${ }^{12}$ The percentages also appear to be independent of the availability of various types of firearms, remaining steady (and low) despite the greater number of long guns than handguns throughout the population and despite the surge in availability of handguns in recent years. ${ }^{13}$ These data strongly suggest that some factor other than availability of long guns affects the decision to use them in homicides generally and, presumably, in spousal homicides as well.114 Even if people acquired long guns to replace banned handguns for self-protection, a belief that a rifle or shotgun would be substituted for a handgun by an offender spouse is based on mere speculation. Only additional social science research can resolve this question.

If the government implemented a system of licensing as a gun control policy, rather than banning handguns, the goal of the system would be to predict who would later misuse the weapon and thus should be denied the license. This problem is particularly imposing to the extent that spousal homicide is conceptualized as a crime of passion committed by average

106. See supra text accompanying note 26.

107. See supra text accompanying notes 27-31.

108. D. Mulvihill, M. Tumin \& L. Curtis, supra note 2, at 236; G. Newton \& F. Zimring, supra note 6 , at $43-44$

109. See UCR, supra note 3 , for the following years: 1966 , at $7 ; 1967$, at $7 ; 1968$, at $7 ; 1969$, at 7 ; 1970 , at $8 ; 1971$, at $8 ; 1972$, at $8 ; 1973$, at $9 ; 1974$, at $17 ; 1975$, at $17 ; 1976$, at $9 ; 1977$, at $10 ; 1978$, at $12 ; 1979$, at $12 ; 1980$, at $13 ; 1981$, at $12 ; 1982$, at $10 ; 1983$, at 10 .

110. See UCR, supra note 3 , for the following years: 1966 , at $5 ; 1967$, at $7 ; 1968$, at $7 ; 1969$, at 6 ; 1970 , at $8 ; 1971$, at $8 ; 1972$, at $6 ; 1973$, at $6 ; 1974$, at $15 ; 1975$, at $15 ; 1976$, at $8 ; 1977$, at $8 ; 1978$, at $8 ; 1979$, at $7 ; 1980$, at $8 ; 1981$, at $7 ; 1982$, at $7 ; 1983$, at 7 .

111. See UCR, supra note 3 , for the following years: 1966 , at $7 ; 1967$, at $7 ; 1968$, at $7 ; 1969$, at 7 ; 1970 , at $8 ; 1971$, at $8 ; 1972$, at $8 ; 1973$, at $9 ; 1974$, at $17 ; 1975$, at $17 ; 1976$, at $9 ; 1977$, at $10 ; 1978$, at $12 ; 1979$, at $12 ; 1980$, at $13 ; 1981$, at $12 ; 1982$, at $10 ; 1983$, at 10 .

112. Although the commentators agree that long guns outnumber handguns, reliable gun ownership statistics are not available. Cf. G. Newton \& F. Zimring, supra note 6, at 76. Thus, the estimated ratio of long gun to handgun availability varies from two to one, Kates, supra note 80 , at 33 (citing an unpublished paper by Kleck), to five to one, Benenson, supra note 96, at 735 .

113. Zimring, Firearms and Federal Law: The Gun Control Act of 1968, 4 J. LEGAL STUd. 133,148 (1975). Long guns also have become increasingly plentiful. Kates, supra note 5, at 21.

114. No data are available concerning the use of long guns versus handguns in spousal homicide since figures are not broken down beyond the firearms category. Even Wolfgang did not report weapons usage for all cases with this degree of specificity. 
citizens who were simply pushed too far, because licensing procedures are unlikely to isolate these individuals. If these offenders are law-abiding citizens until their act of killing, they would be able to obtain a license for a gun. ${ }^{115}$

Just as a history of violence is the best predictor of wife abusers, ${ }^{116}$ a history of violence often precedes the murder of a spouse. 117 To deny gun licenses to individuals having a history of domestic disturbances, however, raises several problems. First, violence is so prevalent in our society that a disability based upon a violent history would be grossly overinclusive, ${ }^{118}$ failing to accomplish the objective of the legislation and raising possible constitutional problems. ${ }^{119}$ Second, an underinclusion problem might arise since many abusive individuals would not be identified if arrest records were the basis for denying a gun license, given the notorious reluctance of police to make arrests in wife beating cases. ${ }^{120}$ Third, use of convictions would be even further underinclusive, since prosecutors often choose not to prosecute spouse abusers, ${ }^{121}$ although this approach produces fewer constitutional objections. Disability based on felony conviction is part of existing gun control law, ${ }^{122}$ however, and perhaps proves, by its ineffectiveness, ${ }^{123}$ the impotence of this and similar approaches in reducing spousal homicides. Fourth, an approach based on a history of violence usually fails to identify wives, who constitute nearly half of all spouse killers and who often lack a violent background.

On the other hand, if a licensing statute included a mandatory waiting period and if the household, like the majority of households, did not own a handgun, then a spouse motivated by momentary anger to apply for a license might cool off and decide to forego the gun purchase. A spouse who went ahead and purchased the gun, however, would most likely consciously intend to use it either offensively or defensively the next time a domestic argument arose. This intention seems perilously close to a determination to kill.

Most of the preceding discussion is rank speculation and brings us no closer to knowing whether gun control measures could reduce the incidence of husband-wife homicides. How, then, can society reduce these crimes?

At the outset, one should note that although the rate of spousal homicide has declined over the last decade without the benefit of severe or confiscatory

115. Benenson, supra note 96, at 738-39; Kaplan, supra note 91, at 22.

116. Walker, supra note 36 , at 37 .

117. See supra text accompanying notes 37-39.

118. Straus and his colleagues estimate that violent acts are committed by one spouse against the other, over the life of a marriage, in $28 \%$ of marriages. M. Straus, R. Gel.tes \& S. Strinmer\%, supro note 43 , at 32 .

119. C. Hardy \& Stompoly, supra note 4, at 96 n.192.

120. See. e.g. Fields, supra note 39, at 229-49; Martin. supra note 42, at 209-13.

121. See, e.g. Fields, supra note 39, at 249-56.

122. For a discussion of the Gun Control Act of 1968, sec 7imring, supura note 113

123. Studies show that a record of prior convictions is not an indicator of future murderers. Hardy \& Stompoly, supm note 4, at 95-96. Only 25\% of homicide offenders have prior felony convictions, Kleck \& Bordua, supra note 6. at 95; see also Zimring, supra notc 113, at 170-94. 
gun control legislation, ${ }^{124}$ this decrease is attributable to sharp increases in other categories of homicide, rather than to significant changes in the spousal homicide pattern. ${ }^{125}$ Persons wishing to perpetuate this trend should seek to identify and reinforce the nonstatistical factors contributing to this decline. At least three such factors are readily apparent.

First, the increase in the last decade of public awareness of the spouse abuse problem has had concomitant impact on increasing the alternatives available to abused women (such as shelters) and reducing psychological barriers to using those resources. Second, many battering relationships end in divorce and the increasing acceptance of divorce, reflected in the escalating national divorce rate, may encourage battered women to end their marriages. ${ }^{126}$ Divorce or separation is, in fact, urged by several commentators as the solution of choice for battering couples. ${ }^{127}$ Third, the decreasing dependency of women, spurred perhaps by the women's movement, may be contributing to a decline in domestic violence and domestic homicide. Research shows that couples who follow an egalitarian pattern of decisionmaking experience a rate of wife abuse substantially lower than couples in which one spouse dominates the other ${ }^{128}$ and that dependency may be a "culprit" in victim-precipitated homicides. ${ }^{129}$ Furthermore, these

124. The rate of spousal homicides per 100,000 households fell from 4.3 in 1970 to 3.9 in 1980 , although the absolute number of spousal homicides has remained fairly stable. See Zimring, Mukherjee \& Van Winkle, Intimate Violence: A Study of Intersexual Homicide in Chicago, 50 U. CHI. L. REv. 910, $912-13$ (1983) (and sources cited therein).

The rate of spousal homicide as a percentage of all homicides has declined dramatically, falling in every year except one since 1966. Spousal homicide, for example, constituted 16.3\% of all homicides in 1966, UCR (1966), supra note 3 , at 7 , but only $8.2 \%$ in 1982 , UCR (1982), supra note 3 at 11 .

The coincidence of this decline in the rate of spousal homicides per 100,000 households (or the relative stability in the absolute number of spousal homicides) and the concurrent increase in handgun ownership provides some evidence that handgun availability does not cause or contribute to spousal homicide. Cf. Kates, supra note 80 , at 19 .

125. Zimring, Mukherjee \& Van Winkle, supra note 124, at 923.

126. The precise role of marital violence in divorce is unclear. One study found that $80 \%$ of battered wives were divorced or divorcing. Eisenberg \& Micklow, The Assaulted "Ife: "Catch 22 " Revisited, 3 WOMEN's RTs. L. ReP. 138, 143 (1977). Another study placed that figure at 50\%. A. Jones, supra note 40, at 297 (citing Flynn, Recent Findings Related to IVife Abuse, Soc. Casework, Jan. 1977, at 18). Domestic violence is a factor in a large number of divorces, although estimates of the exact number vary. Jones placed the figure at one-fourth. Jones, supra note 15 , at 14 . Levinger found that $37 \%$ of wives, but only $3 \%$ of husbands, listed physical abuse by their spouse as a reason for the divorce. Levinger, Sources of Marital Dissatisfaction Among Applications for Divorce, 36 AM. J. ORTHOPSYCHIATRY 803,805 (1966). O'Brien found that $17 \%$ of men and women respondents who had initiated divorce proceedings mentioned violence as a reason for the divorce. Of those $17 \%$, $84 \%$ were women. O'Brien, Violence in Divorce-Prone Families, 33 J. Marriage \& Fam. $692-98$ (1971).

127. Martin, supra note 42, at 222; Walker, supra note 46, at 162-63.

Separation or divorce may not be enough, however. University of Florida researchers found that $56 \%$ of the men studied (who had killed their wives) had been separated from their spouses at the time of the homicide. Jones, supra note 15, at 15. Walker, Thyfault, and Browne reported that some women who killed their battering husbands had been separated or divorced for two years, but were still being threatened or harassed. Walker, Thyfault \& Browne, supra note 54, at 12 . For factual examples of such cases, see $A$. Jones, supra note 40, at 298-99.

128. See supra note 43.

129. Jones, supra note 15 , at 15 . 
findings dispel the notion that emancipation of women poses a threat to the lives of their husbands. ${ }^{130}$

Based upon the foregoing factors, one may speculate that further increasing the options available to battered wives carries more promise of saving lives than does gun control. Thus, additional shelters should be made available and publicized. Police should be enabled and encouraged, through changes in the law ${ }^{131}$ and litigation, if necessary, ${ }^{132}$ to arrest spouse abusers. Admittedly, many proponents of alternatives such as mediation programs dispute the efficacy of arrests, ${ }^{133}$ and these programs may be beneficial . for spouses involved in nonassaultive domestic disturbances. When an assault has occurred, however, the pattern of escalation that may lead to homicide must be interrupted. Mediation is inappropriate at this point, as even its advocates recognize; ${ }^{134}$ arrest is the alternative most likely to stop the beatings and, as a result, the homicides to which they lead. ${ }^{135}$

\section{CONCLUSION}

Spousal homicides differ from other homicides in several important respects. First, although the place a spousal homicide occurs is a determinant of the weapon utilized, husbands and wives appear to shoot each other much less often than homicide offenders overall. Knives and other sharp instruments make up the difference. Second, husband-wife quarrels are more deadly than arguments generally, with a substantial majority of spousal homicides arising out of angry exchanges. Third, spousal homicides are

130. Jones pointed to an example of this notion: "In New Hampshire, the State Commission on the Status of Women, a group whose sole recorded achievement is the designation of the ladybug as the official state insect, turned down a proposal to shelter battered wives on the grounds that wifebeating was caused by feminism." A. Jones, supra note 40, at 320 (emphasis in original); see also Ward, Jackson \& Ward, supra note 15, at 907 (speculating that the trend toward increased violence by women "may be accelerated as women become emancipated from traditional female role requirements").

131. Juanita Stout, a judge in the Philadelphia Court of Common Pleas, argued that all aggravated assaults should be classified as felonies so that police officers mav arrest the offender, upon probable cause, without witnessing the attack or depending upon the victim to obtain a warrant. Stout, supra note 59, at 288-91.

132. See Thurman v. City of Torrington, 595 F. Supp. 1521 (D. Conn. 1984); Bruno v. Codd, 47 N.Y.2d 582, 393 N.E.2d 976 (1979).

133. See generally Bard \& Connolly, The Police and Family Violence: Policy and Practice, in BATTERED Wómen, supra note 39 , at 304.

Bard and Connolly characterize arrest of batterers as the "simple solution" that appeals to traditionally-oriented police officers, $i d$. at $320-21$, but which prevents exercise of discretion to mediate the dispute when appropriate, id. at 319. Characterizing arrest as the comfortable, traditional approach of police officers in domestic violence cases is, however, completely at odds with well-established police reluctance to arrest wife beaters. The alternative to mediation is, in fact, to offer a genuine arrest option to the battered wife.

134. Oral remarks of Morton Bard at United States Commission on Civil Rights Consultation. Jan. 31, 1978, in BATtERED WoMEN, supra note 39, at 50-51 (1978).

135. Shearer, trest the Ilife-Bealers, Parade Mag., Oct. 16, 1983, at 8 (reporting findings of a Minneapolis Police Department study that only $10 \%$ of men arrested for beating their wives repeated the offense within six months, compared with $24 \%$ of men removed for at least cight hours from residences shared with their victims, and $17 \%$ of men involved in mediation). 
among the most violent of all homicides. Finally, while husbands and wives are homicide offenders in roughly equal proportions, victim-husbands frequently provoke the attack upon themselves and offender-wives often act in self-defense.

Coupling these facts with the complex psychological and sociological etiology of wife beating revealed by the spouse abuse literature lends credence to the view that spousal homicide is probably a crime of passion rather than a determined killing. To the extent it is a crime of passion, spousal homicide should respond to enforced legislation banning all guns. Such legislation is unlikely to be forthcoming, however, due to difficulties (impossibilities?) of enforcement and political unpopularity. Registration and licensing programs probably would not affect the incidence of spousal homicides because these gun control schemes would not keep firearms out of the hands of people who will ultimately use the weapons against their spouses. The only alternative left is a handgun ban.

If a ban actually removed handguns from the reach of angry husbands and wives, many of these individuals would simply grasp the most conveniently available alternative weapon, as the data on spousal homicide suggest they are already doing. The substituted weapon would probably be a knife and increased use of knives might decrease the number of fatalities, given the lower lethality of knives as compared with guns. The most noticeable effect of a handgun ban, however, might actually be to remove a battered woman's best defensive weapon.

The rate of spousal homicide is decreasing steadily, even in the absence of effective nationwide gun control legislation, largely for nonstatistical reasons. Persons interested in further reducing the lethality of intimate relationships are better advised to identify and strengthen the nonstatistical factors contributing to this decreasing rate. This approach would reduce spousal homicides more effectively than gun controls. 